\title{
Chronic Eosinophilic Leukemia, Not Otherwise Specified
}

National Cancer Institute

\section{Source}

National Cancer Institute. Chronic Eosinophilic Leukemia, Not Otherwise Specified. NCI

Thesaurus. Code C4563.

A rare myeloproliferative neoplasm characterized by a clonal proliferation of eosinophilic precursors resulting in persistently increased numbers of eosinophils in the blood, marrow and peripheral tissues. Since acute eosinophilic leukemia is at best exceedingly rare, the term eosinophilic leukemia is normally used as a synonym for chronic eosinophilic leukemia. In cases in which it is impossible to prove clonality and there is no increase in blast cells, the diagnosis of "idiopathic hypereosinophilic syndrome" is preferred. (WHO, 2001) 